\title{
Big Power Relations under the Framework of the IOR-ARC*
}

\author{
SHU Meng \\ Shanghai International Studies University, Shanghai, China
}

\begin{abstract}
The Indian Ocean Rim-Association for Regional Cooperation (IOR-ARC) has been highlighted in recent years by the Indian Ocean region's growing in strategic and economic importance and the impetus from the participation of the Middle Eastern countries. Many powers, including the U.S., China, Iran, and India, are involved in this organization as members or dialogue partners, which expand the influence of the organization on the one hand, and stand in the way of the integration of the region under the framework of IOR-ARC due to complex contradiction among them on the other. The role of IOR-ARC in diplomacy of different powers is various from an economic platform for expanding market to a political tool for pursuing regional dominance without a common strategic focus. The IOR-ARC provides a shared public platform of geopolitics for stakeholders to prevent overlapping interests from causing conflicts, and the stumbled cooperation process after initial general enthusiasm also reflects diverging interests inside it. In this regard, powers are both driving and dragging force to the organization. The IOR-ARC is of great potential as it includes many emerging economics and fastest-growing markets. However, the future development and efficiency of it still depends on the relationships among global and regional powers under its framework.
\end{abstract}

Keywords: IOR-ARC, Indian Ocean, powers relationship

\section{Introduction}

The Indian Ocean Rim-Association for Regional Cooperation (IOR-ARC) has been highlighted in recent years by the Indian Ocean region's growing in strategic and economic importance and the impetus from the participation of the Middle Eastern countries. Proposed by Mauritius in 1995 and established in 1997, the IOR-ARC has 21 member states and seven dialogue partners till November 2017, with the aim to promote the continuous and even development of the whole region. The role of IOR-ARC is without doubt worth to be attached importance, for several reasons: From the economic perspective, the trade involving member states of the association plays a vital part in global economy currently. The IOR-ARC aggregates the comparative advantages in technology, resources, capital, and labor of member states with different development levels in the area to achieve complementary advantages and promote blue economy. From the political perspective, due to the rising importance of the region in the world, powers eager to exert influence and protect or obtain interests in the Indian Ocean region, in which the IOR-ARC provides a shared public platform of geopolitics for members to prevent overlapping interests from causing conflicts or confrontations. From the security perspective, the maritime trade routes in the India Ocean are among the key areas in global economy, while

\footnotetext{
* Acknowledgement: This article is supported by 2016 Chinese National Social Science Fund project (16ZDA096).

Shu Meng, Ph.D. in diplomacy, assistant researcher at the Middle East Studies Institute of Shanghai International Studies University, Shanghai, China.
} 
areas where the extremism problems are relative serious-Arabian Peninsula and Somali Peninsula-are all located in the India Ocean region. Therefore, the IOR-ARC is worth focusing upon as a basis for the future peaceful development and stability of the region. In recent years, many global and regional powers, including the U.S., China, Iran, Australia, and India, are involved in this association as members or dialogue partners, which expand the influence of the association, on the one hand, and stand in the way of the integration of the region under the framework of IOR-ARC due to complex contradiction among them on the other. Against such backdrop, this chapter aims to analyze the development and problems ahead of the IOR-ARC from the perspective of big power relations.

\section{Importance, Achievements, and Challenges of the IOR-ARC}

\section{Importance of the IOR-ARC}

The IOR-ARC has drawn increasing global attention present days, the importance of which is mainly based on the importance of the Indian Ocean, as follows:

First, the geopolitical location of the Indian Ocean and the Indian Ocean Rim region: The unique location of the Indian Ocean has drawn interests of the powers and led to intensified game among major countries of the world. The ocean has long coastal line and some waterways in throat positions. The Indian Ocean Rim covers the most extensive waters over the world and includes 45 coastal countries from the Asian continent, the African continent, and the Australian continent. The IOR-ARC across Asia, Africa, and Oceania has wide market and convenient transportation. The Suez Canal, Cape of Good Hope, Gulf of Aden, and Oman Bay are all important maritime routes inside, and the Mande Strait, the Strait of Hormuz, and the Straits of Malacca in the region are also important in global trade. There are as many as 40 percent of the global trade traverses through Indian Ocean. ${ }^{1}$

As the bridge connecting the Atlantic and the Pacific, Asia, and Europe, the Indian Ocean plays a role as the sea lifeline of many countries. To countries within the association, maritime trade routes in the Indian Ocean are key to their national, regional, and even global trade. With the growth in Asian economics, its energy and trade exchanges with countries along the Indian Ocean have been increasing. The strategic importance of the region has drawn wide attention, and the unique geopolitical location makes it possible for the geo-values of this association.

Second, the rich natural resources in the Indian Ocean Rim: The mineral and energy resources are very diversified in this region. The famous regions for energy reserves, the Persian Gulf, is located in this area, in which the oil reserves account for more than a half of the world and the natural gas reserves account for almost a half. Many countries in this region are rich in different resources. For instance, Indonesia and Malaysia are rich in natural gas; Australia, India, and countries in South Africa have huge coal storage; and Australia and South Africa are rich in mineable uranium. In the previous century, energy has played a vital role in geopolitical games among powers. In a foreseeable future, energy will remain very much important in global geopolitics.

Hence, the importance of the Indian Ocean has always been highlighted. Since the new century, with the rise of emerging countries, the prosperity of maritime trade, the turbulence in the Middle East, and the fully

\footnotetext{
1 AIR spotlight summary on "First Indian Ocean Rim Association Summit", Insights, last modified March 10, 2017, http://www.insightsonindia.com/2017/03/10/air-spotlight-summary-first-indian-ocean-Rim-association-summit/.
} 
carrying out of anti-non-traditional security problems, big powers have intensified their competition on this region. Alfred Thayer Mahan, an American naval officer and historian from the 19th and 20th centuries, said that "whoever controls the Indian Ocean dominates Asia. This ocean is the key to the seven seas in the 21st century, the destiny of the world will be decided in these waters". Also, similar, as the former Chief of Indian Naval Staff Arun Prakash said, the Indian Ocean Region is set to become the economic and geo-political fulcrum of the 21 st century. ${ }^{2}$

Located in such a key area, the importance of the IOR-ARC goes without detailed analysis. Besides the geopolitical importance, the economic role of this association is also notable. The IOR-ARC is the first big regional economic cooperative organization in the Indian Ocean Rim area, and the only economic cooperative organization that includes the whole Indian Ocean region. After the EU, North American Free Trade Area (NAFTA), and Asia-Pacific Economic Cooperation (APEC), the IOR-ARC is the fourth economic group in the world. The economic development level of the IOR-ARC not only determines the level of economic cooperation in the Indian Ocean in future, but also affects the recovery and growth of global economy.

\section{Achievements Made by IOR-ARC}

After 20 years' development, the IOR-ARC has mainly made several achievements (Shi, 2014):

First, members of the association have increased. Established in 1997, the IOR-ARC had only 14 member states. This number climbed to 21 after two decades. Many major countries in the world have become the dialogue partners of the association, including the U.S., China, Japan, Egypt, the UK, France, and Germany. The involvement of these big powers has greatly expanded the influence of the association.

Second, level of economic and trade cooperation within the region has been improved.

The IORA's vast coastline holds two thirds of the world's oil reserves, carries half of the world's container ships and one third of the bulk cargo traffic and produces goods and services worth over US\$1 trillion, with intra-IORA trade amounting to some US\$777 billion. ${ }^{3}$

The association advocates the four principles on trade and economic cooperation, to promote free trade, investment facilitation, economic and technology cooperation, and trade and investment dialogues. In March 6, 2017, the summit of the IOR-ARC was held in Jakarta, Indonesia, during which members reaffirmed to promote cooperation and promote regional prosperity. The blue economy, which is the unique advantage of the association with great potential, has been highlighted frequently in summits of the association these years.

Third, scope of cooperation of the IOR-ARC has been expanded from economic and trade cooperation to cooperation in various fields, including non-tradition security cooperation in particular. Of course, till now, the emphasis was more on economic integration and economic collaboration. However, it has already shown the momentum to focus more on security issues. According to the Insights, in the spotlight summary on "First Indian Ocean Rim Association Summit", members agreed to

focus more on security issues in Indian Ocean Region and make sure that there is no entry of foreign navy in a manner which can disturb the peace and tranquillity of the region; otherwise, they will be opening the region for competition which will eventually harm all the countries.

\footnotetext{
2 Importance of Indian Ocean-Rim region stressed, World News.com, accessed April 20, 2017, http://article.wn.com/view/2016/10/15/Importance_of_Indian_OceanRim_region_stressed/.

3 President Zuma arrives in Indonesia for Indian Ocean Rim Association Summit and State Visit, Africa Newswire, accessed November 29, 2017, https://africanewswire.za.com/president-zuma-arrives-in-indonesia-for-indian-ocean-Rim-association-summit-and-state-visit/.
} 
And reached the consensus that how to secure the maritime sea routes is a difficult task but doable if all the IORA countries cooperate.

Admittedly, the IOR-ARC has made many achievements in the previous 20 years. However, it is also notable that the achievements are disproportionate with the huge population and the large area that the region accounts for in the whole world. This is mainly because of the problems and challenges of the association.

\section{Challenges of the IOR-ARC}

The challenges of the IOR-ARC are mainly from following aspects:

First, unstable social environment: Across Southeast Asia, South Asia, West Asia, and East Africa, the politics, population, culture, economy, and religion of the countries in the Indian Ocean Rim area are diversified. The Indian Ocean Rim region has always been the security problem-prone region. There are many failed countries, from the Middle East, Africa East Coast to South Asian and Southeast Asia. Many countries face complex domestic problems, such as poverty, extremism, political unrest, ethnic separatist forces, and religious extremism and terrorism threats. Political situation is very unstable in some countries, including Somalia, Yemen, Iraq, etc., which greatly affects the peace and stability of the Indian Ocean region. This region contains many potential conflict zones, such as the areas around Afghanistan, border areas between India and Pakistan. The Indian Ocean Rim region is the also a region prone to meet natural disasters, such as tsunami or strong tropical storm. The natural disasters worsen the livelihood of the people in countries along the ocean, coupled with domestic problems, producing non-traditional security threats.

Second, impacts from external forces: Military interventionism, interference with local politics, military aid, and arms supply of external forces areas have largely contributed to the instability of the Indian Ocean Rim area. Intervention from the external forces has induced or intensified internal problems, such as weak governance ability of some countries, competition for recourses, cultural intolerance, and extremism ideologies.

Third, overlapped associations around the Indian Ocean Rim region: Although the IOR-ARC is the first big regional economic cooperative organization in the Indian Ocean Rim area and the only economic cooperative organization that includes the whole Indian Ocean region, it is not unique to its member states. Many countries participate in regional or global organizations, expecting to maximize their benefits through transferring a part of their national sovereignty. However, the part of national sovereignty that they could transfer is not infinite, which determines that these countries should prioritize the regional or global organizations they participate in. In areas surrounding the Indian Ocean Rim region, there have been many regional or global organizations. There are 14 international or regional organizations that overlap with the IOR-ARC (see Table 1). There organizations have played important role in regional cooperation and economic integration, while members of these organizations are overlapped with members of the IOR-ARC. How to coordinate with other regional organizations and play its unique role is the question ahead of the IOR-ARC. 
Table 1

Regional or International Organizations Overlapped With the IOR-ARC

\begin{tabular}{|c|c|c|c|c|}
\hline & Organization & Headquarters & Focuses & Members \\
\hline 1 & $\begin{array}{l}\text { South Asian Association for Regional } \\
\text { Cooperation }\end{array}$ & Kathmandu & $\begin{array}{l}\text { Economic cooperation; } \\
\text { Topics with common concern }\end{array}$ & 8 \\
\hline 2 & ASEAN & Jakarta & Comprehensive cooperation & 10 \\
\hline 3 & African Union & Addis Ababa & Comprehensive cooperation & 54 \\
\hline 4 & ASEAN Regional Forum & Kathmandu & Comprehensive cooperation & 27 \\
\hline 5 & African Development Bank & Abidjan & Development & 78 \\
\hline 6 & Asian Development Bank & Manila & Development & 67 \\
\hline 7 & $\begin{array}{l}\text { Bay of Bengal Initiative for Multi Sectoral } \\
\text { Technical and Economic Cooperation }\end{array}$ & Dhaka & Multi-field cooperation & 7 \\
\hline 8 & Southern African Development Community & Gaborone & Comprehensive cooperation & 15 \\
\hline 9 & Gulf Cooperation Council & Riyadh & Comprehensive cooperation & 6 \\
\hline 10 & 0 Asian Pacific Economic Cooperation & Singapore & Comprehensive cooperation & $\begin{array}{l}21 \text { countries } \\
\text { and regions }\end{array}$ \\
\hline & 1 Arab League & Caro & Comprehensive cooperation & 22 \\
\hline 12 & 2 Asian Cooperation Dialogue & Thailand & Economic cooperation & 31 \\
\hline 13 & 3 Colombo Plan & Colombo & $\begin{array}{l}\text { Economic and social development; } \\
\text { Human recourses }\end{array}$ & 27 \\
\hline 14 & $\begin{array}{l}\text { South West Indian Ocean Fisheries } \\
\text { Commission }\end{array}$ & Maputo & Fisheries management & 9 \\
\hline
\end{tabular}

Note. Source: Liu (2015).

Fourth, the low efficiency of the association: To avoid unnecessary trouble, the association insists the principle of consensus in making decisions and does not discuss issues that may arouse controversy or undermine bilateral relationships in regional economic cooperation (Sugandha, 2008). Such non-intrusive cooperation sometime led to a problem that the cooperation within the framework of IOR-ARC is often bilateral instead of multilateral. The IOR-ARC has not worked as a whole, which greatly undermined its efficiency (Vines \& Oruitemeka, 2008).

On the one hand, such principle has prevented some controversial trouble from taking place, while on the other hand, the efficiency of the association has also been undermined, since so many countries are included in the association without widely accepted leaders. 
The challenges of the IOR-ARC are deep-rooted in two problems: Firstly, the integration level is still not deep enough to integrate the resources in the region; countries in different development levels with diversified conditions still develop in their own ways. Secondly, the cooperation level among the countries is not enough; hence, the role of the association has been repressed. To promote the integration and cooperation level, the cooperation among big major countries in or involved in this association is urgent required.

Major power relations are quite complex in this region. In 1991, the U.S. military forces withdraw from the Subic Bay in the Philippines, and one year later, the Soviet Union withdraws most of its military forces from Vietnam's Cam Ranh Bay. After then, the region has been in power vacuum relatively. Due the phenomenon that there is no effective international institution or organization in the Indian Ocean Rim region to restrict competition among powers, the powers' competition has been intensified. More and more big powers all over the world get interests to this region and try to get more right to speak in making rules of procedures of this region, which complex the big-power relations around the Indian Ocean Rim region. Based on this, this chapter will next analyze the major power relations in the framework of the IOR-ARC and try to predict the future development of this association based on the interaction of the major powers.

\section{Major Contradictions among Countries in the IOR-ARC}

The IOR-ARC is an association involving many emerging economies and markets with the fastest growth. Against the backdrop of the increasing importance of the Indian Ocean Rim region, especially with the constraints of land resources and the development of the oceanic recourses, countries in this region and outside power all expand its presence and face the competition on marine space, resources, routes, trade and influence with others, and contradictions are therefore produced. Generally speaking, contradictions of the countries in the IOR-ARC can be divided to several types-historical contradictions among countries in the IOR-ARC, represented by historical dispute between India and Pakistan, contradictions among emerging powers, represented by the competition between China and India and contradictions between traditional powers and emerging powers, proved by divergence between the U.S. and India. Among the contradictions, the contradiction between China and India is most worth noting.

\section{Contradictions between China and India}

There are many emerging markets among the members and dialogue partners of the IOR-ARC, such as China, India, Indonesia, Malaysia, and Thailand, and the most represented contradictions among emerging powers are the cooperative and competitive relationship between China and India.

The rise of China and India is among the biggest changes in geopolitics in the 21st century, which has also affected the geopolitical pattern around the Indian Ocean. Both China and India are putting efforts in integrating into the global economics and expanding their overseas market. With the attractive market potential and broad investment opportunities, Indian Ocean Rim region has been focuses by both. Against such background, some scholars predict that there is doom to have conflicts between China and India around the Indian Ocean. A book entitled Sino-Indian Rivalry in the Indo-Pacific, written by Indian strategist C. Raja Mohan (2014) is a representative. In the book, Mohan holds that China has shifted its focus to the Indian Ocean, and India begins to focus on the Pacific, which leads to the upgrade of the security dilemma between two powers. He also holds that the two sides have all attached more importance to compete for regional dominance in the Indian Ocean Rim area (Kaplan, 2011; Brewster, 2015; Unjhawala, 2015). India's policy has transformed 
from "Look East" to "Act East", reflecting its longing for the dominance role in the Indian Ocean. Economically, China and India are interdependence in trade and economic exchanges. Two countries have already tried to deal with the imbalance in bilateral trade. Politically, however, due to the historical unsolved territorial dispute, the mutual trust between China and Indian has been lacked.

Both the two sides are quite active in the IOR-ARC.

From the Indian perspective, it is a major power in South Asia and the Indian Ocean region. The Indian Ocean has been a fulcrum of Indian diplomacy. It has great strategic, political, and economic interests in this region. India wants to take full use of such advantage to play an important role in the IOR-ARC to expand its regional and even global influence and improve its international status. The establishment of the IOR-ARC has promoted the economic exchanges between India and countries along the coastal countries in West Asia and Africa, and even countries in European countries and Southeastern and South Asian countries. The association could also provide a healthy surrounding environment for India to promote its global strategies. Through the IOR-ARC, India wants to integrate the comparative advantage of countries in the association on technology, resources, capital, and labor to achieve complementary advantages, create more trade opportunities, so as to form an influential regional group that could contend with other regional organizations. Hence, India's participation in the IOR-ARC is not only aimed for economic interests, but also aimed to play a dominant role in the association, in order to further play a dominant role in the whole Indian Ocean Rim region. India has long worried that China may make use of its status as a dialogue partner to improve its influence in the association, and further expand its presence in the region.

On the other side, China has been the important factor that could influence the economic exchange between India and countries in the Indian Ocean. The southwest frontier of China is closed to the Indian Ocean; hence, the stability of the north shore of the Indian Ocean is directly related to China's geo-security. Besides, the Indian Ocean and straits in the Indian Ocean Rim area are important channels for China's trade transportation, making it possible for the international trade between China and other countries in Asia, Africa, and the Europe. Besides, from the energy perspective, China's dependence on the Persian Gulf has been growing serious. The Indian Ocean, connecting the Persian Gulf and the South China Sea, is an important channel for China's energy imports. Therefore, although China locates outside the Indian Ocean region, it is a country with significant interest concerns, since the Indian Ocean is related to political stability and economic sustainable development of China. Based on such considerations, as early as 2000, no more than three years after the establishment of the association, China became a dialogue partner of the IOR-ARC. The dialogue partner is different from members, they have not voting rights; what they could do is just to give suggestions to member states. However, China has long been the important element in development of Indian Ocean economic cooperation and the IOR-ARC. The trade between China and the members and partners of IOR-ARC accounts for the majority of China's international trade. During the 9th ministerial meeting of the IOR-ARC held in Yemen, Chinese ambassador to Yemen Luo Xiaoguang said that China will expand its participation in the IOR-ARC through carrying out substantive cooperation to jointly cope with international financial crisis, deepening regional cooperation and launching dialogues, as well as improving trade and investment facilitation in the Indian Ocean Rim region. ${ }^{4}$ In 2013, Chinese President Xi Jinping proposed the building of " 21 st century

4 IOR-ARC conference was held in Yemen, Chinese Ministry of Commerce, last modified June 27, 2009, http://finance.ifeng.com/roll/20090627/852880.shtml. 
Maritime Silk Road", which is closed related to the IOR's "blue economy" plan. As an official from South Africa, which holds the vice rotating presidency of the association, said during the Blue Economy Seminar of the IOR-ARC held in Qingdao in 2016, South African Deputy Director-General of the Department of International Relations and Cooperation Anil Sooklal expressed that the proposal of the "21st century Maritime Silk Road" has brought opportunities to member states of the IOR-ARC; members of the IOR-ARC need the huge market and advanced technologies of China, and China also need complementary products and markets.

It can be found that as an external power, China's participation in the IOR-ARC is mainly limited in economic area. Currently, problems have already emerged in its economic relationship with India with the trade expansion of China in the Indian Ocean area, while it is still controllable and cannot reverse the big picture of the increasing trade cooperation. However, with the shift of the focus of the association from economics to security issues, China's involvement in the region will be overlapped with India's sphere of influence. Coupled with the historical dispute between the two and the lack of mutual trust, the relationship between China and India may stand in the way of the development of the IOR-ARC.

Economic imbalance between the two is easier to be dealt with, since there is still great potential of cooperative space for the two. Both sides indeed have common interests, which is the foundation for cooperation, in aspects, such as maritime energy and trade channels guarantee and maintaining regional stability and peace. However, strategic rivalry between the two on the Indian Ocean will be more difficult to manage. In such a case, a highly effective platform is needed to coordinate the bilateral relations on Indian Ocean related issues and prevent potential conflicts from happening from the very beginning, which should be among the development directions of the IOR-ARC.

\section{Contradiction between Traditional Power and Emerging Powers}

The contradictions between traditional powers and emerging powers within the framework of the IOR-ARC are mainly reflected in the contradiction between the U.S. and India and China. Since the Indian Ocean is not the main stage for the contradiction between the U.S. and China, the chapter will focus more on the contradiction between the U.S. and India.

Although the U.S. and India has intensive interaction and cooperation over the Indian Ocean, there are still divergence and disagreements between the two sides. In 2012, during then Secretary of the State Hillary's visit to South Asia, as the Times Now, a TV program based Mumbai, Hillary wanted to dispatch fleet in Mumbai, which has caused huge oppositions from India. Later, the news was proved to the fake, while it has reflected the mistrust and sensitive feeling between the U.S. and India. ${ }^{5}$ Increasingly, India maintains its strategic interdependence, which led to its different opinion from the U.S. on issues including climate change, reform of international economic system, and Middle East hotspots. For instance, on the issue of Afghanistan, the U.S. is reducing its forces in Afghanistan, while India still worries about this country due to the consideration on Pakistan and the expand of terrorism. Many policies of India are made from the perspective of developing countries, which doomed to be different from some of the U.S.

In the framework of the IOR-ARC, India actively promotes to develop the U.S. as the dialogue partner of the association, which is mainly aimed to balance the expanding of Chinese influence. However, if the U.S. is deeply involved in the association, India's dominant role will be undermined. With the expanding of the

\footnotetext{
5 No Plan on US Base in Chitagong, The Daily Star, June 4, 2012, accessed April 20, 2017, htp://www.thedailystar.net/newDesign/news-details.php?nid=236906.
} 
cooperative fields of the association and with the security issues get more concerns from the association, the U.S. and India, standing on the different level of the world, will without doubt have growing divergence. Due to its interdependent principle, India has been maintained its political sensitivity in U.S.-led associations in Indian Ocean. Although the defense cooperation between the U.S. and India has been heating, interdependence policy has always been the cornerstone of India's foreign policies. India has to make a balance between its pursuit for dominant role in the region and its cooperation with the U.S.

\section{Contradictions Brought by Divergence in the Development Level of Countries}

Both rich countries and poor countries are included in this region. According to the World Development Indicators, more than a half countries located in the Indian Ocean Rim area are countries with medium or low income. Most countries with low income are from Africa, including Somalia, Kenya, Tanzania, and Mozambique. The economies in Bangladesh from South Asia and Myanmar from Southeast Asia, are also relative undeveloped. Per capita income in Egypt, India, Indonesia, Sri Lanka, and Yemen is a little bit better, ranging between $\$ 1280$ to $\$ 3,570$, while the per capita GDP in Thailand, South Africa, Maldives, Mauritius, and Malaysia ranging from $\$ 4,351$ to $\$ 7,624$. Countries from the Gulf, Oman, and Singapore are ranked in countries with high-level income. ${ }^{6}$ The GDP of India was $\$ 2.264$ trillion, while it was 1.427 billion in Seychelles, differing by almost 158.6 times. $^{7}$

The imbalance of the development level is the precondition for economic complementarity on the one hand; it is also an unfavorable factor to regional development on the other hand. The divergence in development level may lead to uneven sharing of the benefits made by economic cooperation, and contradictions may be aroused then. Hence, it will be difficult for members of the IOR-ARC to take unified pace in economic cooperation.

Most countries are undeveloped countries in the IOR-ARC, except for Australia. Because the majority of the members of the association are undeveloped, these countries share common condition with weak economic foundation, poor trade complementarity and competition for exporting products. Although Australia is a developed country, the products it exports also give priority to agricultural products, which may have conflict with some other member states. Also, industrial structures of the member states are quite similar in the IOR-ARC. Due to historical reasons, many countries in the Indian Ocean were places of the raw material supply and dumping of manufactured goods. Similar of the industrial structures in this region stands in the way of commodity exchanges among regional countries and reasonable industrial division.

\section{Historical Contradictions between Countries}

Historical contradictions have always been the stumbling blocks of the regional organizations, same as the IOR-ARC. For instance, the territory dispute between India and Pakistan has been affecting the cooperation between the two countries for years. Also, traditional religious problems, such as the contradiction between Hinduism and the Islam, are all undermine the unity of the association.

\footnotetext{
6 Adjusted net national income per capita (current US\$), the World Bank, accessed November 29, 2017, https://data.worldbank.org/indicator/NY.ADJ.NNTY.PC.CD.

GDP (current US\$), the World Bank, accessed November 25, 2017, http://data.worldbank.org/indicator/NY.GDP.MKTP.CD?locations=IN-SC; Seychelles, the World Bank, accessed November 25, 2017, https://data.worldbank.org/country/seychelles; India, the World Bank, accessed November 25, 2017, https://data.worldbank.org/country/india.
} 
Take the contradiction between India and Pakistan as example. Located also in the Indian Ocean area, Pakistan is not a member of the IOR-ARC. The Pakistan side accused that India has obstructed Pakistan to join region trade groups, making it cannot enjoy preferential trade treatment from neighboring countries. According to the India's Financial News, Pakistan's expectation on joining the IOR-ARC was opposed by India. ${ }^{8}$ Moreover, the dispute between India and Pakistan also affects India's attitude to China, even the latter is only a dialogue partner of the IOR-ARC. Due to the building of the China and Pakistan Economic Corridor, after several conferences have been among members and dialogue partners on the docking of the IOR-ARC's blue economy with China's Belt and Road Initiative, India becomes the only South-Asian country do not attend the "Belt One Road Forum" in 2007, for the reason that, as the External Affairs Ministry Spokesman Gopal Baglay said, "We are all for promoting connectivity...but on the B\&R, our position is that since the so-called CPEC forms a part of $\mathrm{B} \& \mathrm{R}$, and it passes through Indian territory, that is where our difficulty lie", according to the reports of the Indian Express. ${ }^{9}$

Stalled in historical disputes will be conducive to nothing but create a lose-lose situation. Since the disputes cannot be solved overnight, the only way forward is to put the disputes aside and focus more on development and regional cooperation. The role of the IOR-ARC will be unique among other regional organizations if it could play a role in providing a platform for contradiction shelving and resolving in the future.

\section{Major Power Relations and the Prospect of the IOR-ARC}

Based on the analysis on the contradictions among countries in the framework of the IOR-ARC, it can be found that there are mainly three types of countries in the association:

The first type is the countries who view the IOR-ARC as a political tool to compete for regional dominances or expand their regional influence. The U.S. and India are typical two countries in or involved in this association. Guided by such driving force, these countries' participation in the association is targeted. These countries are always in a very positive position of the association and try to play the leading role of the major events of the association, which, to a certain extent, is conductive to the association on the one hand, because the development of the IOR-ARC cannot be achieved without the promoting of such kind of countries. On the other hand, however, these countries' participation in the building and agenda setting of the association has always been exclusive when came to issues related to their strategic interests, due to their pursuit for regional dominance which most of the times cannot be shared. It will affect the future expansion and development of the association, and will also undermine the in-depth cooperation within the association. Besides, such kind of countries, most of the times, participate in many other similar regional or global organizations. As long as the efficiency of the association has not been largely improved or the association is dominated by countries with divergence, the focus of these countries may shift to other organizations.

The second type is the countries that view the IOR-ARC as an economic platform for regional cooperation. Australia and South Africa are two countries in this type. To these countries, the IOR-ARC is a mean for them

\footnotetext{
${ }^{8}$ Pakistan is skeptical about the resumption of trade between India and Pakistan, India's Financial News, May 27, 2003. Cited by Economic and Commercial Counselor's office of the embassy of China in India, last modified May 29, 2003, http://in.mofcom.gov.cn/aarticle/jmxw/200305/20030500094854.html.

9 What is China's One Belt One Road (OBOR) project?, The Indian Express, May 14, 2017, accessed April 5, 2017, http://indianexpress.com/article/what-is/china-one-belt-one-road-project-obor-4653564/.
} 
to open to the outside and expand their targeted markets. Besides economic issues, these countries expect that the association could guarantee the security of their trade, which is also out of the consideration of their economic interests. They are active in participating in the economic cooperation in the association, while they cannot greatly promote the deep cooperation among the members. Also, with the development of the association, the fields covered by the association has been expanded, not only include economic cooperation, but also security maintaining. Against such backdrop, these countries' attitude toward the association still has uncertainties. In short, the participation of these countries cannot exert great impacts on the future development of the association.

The third type is other countries left in the association. These countries are relatively passive in the association. They enjoy the benefits of brought by the cooperation among the association members, while they cannot affect, or have no will to affect the future development of the association. For them, the IOR-ARC is not as important as a useful tool politically, nor an efficient platform economically due to the still existing tariff barriers among the members. Through data analysis on the trade of the members of the IOR-ARC, a Chinese scholar finds that the gap between the member of IOR-ARC with the highest trade volume and the member with the lowest has increased in the past two decades since the founding of the association. Hence, he holds that the role of the IOR-ARC has played little role in economic development of the India Ocean Rim (Liu, 2015). If it is the case, the IOR-ARC's role for these countries is very tiny.

In future, no country in the IOR-ARC is likely to play a dominant role: As for India, its ambition over the Indian Ocean has already aroused the suspicious from small countries in this area; they do not want the India Ocean to change into India's Ocean. Coupled with the presence of other major powers of the world and its disputes with neighbors and its domestic problems, India cannot become the strong regional leader in a seeable future. As for Australia, although it is a developed country in the IOR-ARC, neither could it play a dominant role because it is not an Indian Ocean country in the traditional sense. As for influential dialogue partners, China faces the similar phenomenon as Australia does in this regard. Besides, China has not enough will to compete with India for reginal dominance over the Indian Ocean; its participation in the IOR-ARC is mainly driven by its overseas interests, especially economic interests. Actually, China's military presence in the Indian Ocean is limited. Besides, China's strategic focus has been in East Asian-West Pacific, instead of the Indian Ocean. The U.S. has had presence and influence over the Indian Ocean, while the influence and efficiency of the association dooms that the association is not the focus of the U.S. Also, after the taking power of the Trump administration, the U.S. may shrink its presence overseas.

Therefore, in a seeable future, major power relations in the IOR-ARC will remain co-existing and mutual balanced. In general, the IOR-ARC has play a dual role: On the one hand, the IOR-ARC has provided a new platform for regional countries and surrounding countries, to have more opportunities of communication, cooperation and mutual understanding, which could adjust the relations of the countries in it, prevent some conflicts from taking place. On the other hand, on some occasions, it could also be used as the tools of the major countries for their pursuits for political goals. In this regard, powers are both driving and dragging force to the association.

In future, based on the analysis above, the development of the IOR-ARC will be as follows in different areas:

On economic level, for a long period of time in future, economic cooperation will still be key to the development of the IOR-ARC for mainly two reasons. Firstly, cooperation in other fields is much more 
difficult to be carried out. Secondly, economic development has been among the few achievements that the IOR-ARC has made in previous years; it will become the strongest driving force of the development of the IOR-ARC. However, the economic development is not in isolation; it is also limited by the development of the cooperation among countries in other fields. If the contradictions among countries in IOR-ARC long exist, the region will remain in a fragmented environment, the problems, such as the tariff barriers, still cannot be solved, and the economic development will be groundless then. Therefore, the economic development of the association relies on the higher level of integration and cooperation among members and partners of the association. The accomplishment of this goal calls for efforts from all countries involved in. To big countries, they need to have a tolerant attitude and promote the regional economic cooperation. To small countries, they should be active in upgrading industrial structure, and play their advantage and development economy with their unique advantage, such as blue economy.

On the level of traditional security, the role of the IOR-ARC depends on whether it could maintain the stability of the Indian Ocean region. In present stage, the stability of the Indian Ocean region depends mainly on the balance between the U.S., China, and India, which are the dialogue partners and the member of the IOR-ARC respectively. Viewing from the balance of power, the U.S., China, and India has become three major important forces in the Indian Ocean area. In this triangle structure, the U.S. plays a leading role, and India follows. In such a case, the presence of the IOR-ARC has provided a shared public platform of geopolitics for these stakeholders to prevent overlapping interests from causing conflicts or confrontations. If their overlapping interests and divergence can be solved in the framework of the association, the IOR-ARC will become the important booster for regional stability.

On the level of non-traditional security, issues related to non-traditional security will become another focus of the association. Due to the lack of internal governance in some countries, the expanding of religious extremism forces coupled that it is easily to be affected by changes in international pattern, many non-traditional security problems have emerged in this region. On March 7, 2017, the IORA Leaders' Summit was held in Indonesia's capital city of Jakarta, and proposed to adopt strategic outcome documents entitled "IORA Declaration on Countering Violent Extremism leading to Terrorism", in which "Acknowledging that terrorism in all its forms and manifestations constitutes a serious threat to regional and international peace and security, undermining economic development and social cohesion" and "Recognizing terrorism and violent extremism is not bound by national boundaries and requires cooperation at all levels, local, national, regional, and international to effectively counter, prevent and address conditions conducive to terrorism and violent extremism". ${ }^{10}$ According to the IORA Action Plan 2017-2021, priority area of the association was divided into two parts, maritime security and trade and investment facilitation. The short-term goals of the former are much more detailed than the latter. ${ }^{11}$ Given the conditions that the non-traditional security problems have already been the common challenges ahead of the countries in the IOR-ARC, the cooperation in this regard will continue to develop in next a few years. However, on the other hand, it should be noticed that consideration on self-interests and contradiction among countries will still challenge the cooperation. Besides, in surrounding

\footnotetext{
10 "Indian Ocean Rim Association Declaration on Preventing and Countering Terrorism and Violent Extremism," IORA Secretariat Jakarta in Commemoration of the 20th Anniversary of IORA Documents for the Council of Ministers' (COM) Meeting, Indonesia, March 6, 2017, IOR/COM/20ANNIV/17/DOC3.2.

11 "IORA Action Plan 2017-2021," IORA Secretariat Jakarta in Commemoration of the 20th Anniversary of IORA Documents for the Council of Ministers' (COM) Meeting, Indonesia, 6 March 2017, 2017, IOR/COM/20ANNIV/17/DOC3.1.
} 
areas, there have already had several regional organizations with the non-traditional security problems as their important tasks. Compared with these organizations, besides its uniqueness that it views the Indian Ocean as the key region, the IOR-ARC has not more advantages.

Comprehensively speaking, the future development of the association will still be driven by economic issues, and gradually shift focus to security cooperation. To solve the negative impact of the big power relations on the IOR-ARC, countries should further deepen economic and trade cooperation, enhance the correlation of their national interests, and deduce trade frictions. Members should get together to deal with the challenges, and explore new institutional cooperation in the framework of the association, so as to coordinate with each other to reduce contradictions.

\section{Conclusion}

The Indian Ocean blocks the surrounding countries geographically, while connects them strategically. To bring the sea neighbors together, the role of the IOR-ARC cannot be ignored. In previous years, the IOR-ARC has already made big progress, but challenges are still ahead of the association in its integration and internal cooperation. To promote the integration and cooperation within the IOR-ARC, the cooperation among Global powers and regional powers in or involved in this association is urgent required. In this regard, the roles of the powers are dual.

Global powers and regional powers' involvement in the IOR-ARC as members or dialogue partners expand the influence of the association on the one hand, and stand in the way of the integration of the region under the framework of IOR-ARC due to complex contradiction among them on the other. They are both driving and dragging force to the association.

The IOR-ARC is of great potential as it includes many emerging economics and fastest-growing markets. However, the future development and efficiency of it still depends on the relationships among global and regional powers. Given that the inherent differences among the powers cannot be easily bridged, the powers within the region should attach more importance to the common interests instead of historical disputes, so as to promote the development of the association toward an efficient cooperative platform and prevent it from becoming a tool for powers' competition. The framework of the association has already been established. Powers within are expected to make full use of the platform that the association created and joint together to contribute to the peaceful development of the Indian Ocean Rim Region.

\section{References}

Brewster, D. (2015). An Indian Ocean dilemma: Sino-Indian rivalry and China's strategic vulnerability in the Indian Ocean. Journal of the Indian Ocean Region, 11(1), 48-59.

Dong, Q. A. (2017). On managing affairs concerning the Indian Ocean-China's strategic decision in light of the Belt and Road Initiative. Journal of Jiangnan Social University, 19(3), 32-39.

Kaplan, R. D. (2011). Monsoons: The Indian Ocean and the future of the America. New York: Random House Trade Paperbacks. Liu, P. (2015). Evaluation on international systems in Indian Ocean (Ph.D. dissertation, Jinan University).

Mohan, R. C. (2014). Sino-Indian rivalry in the Indo-Pacific. Report of Carnegie Endowment for International Peace. Retrieved March 21, 2014, from http://carnegietsinghua.org/2014/03/21/samudra-manthan-sino-indian-rivalry-in-indo-pacific/h2rj

Shi, H. Y. (2014). Prospect of Indian Ocean Rim Region Cooperation-Based on Analysis on IOR-ARC. Indian Ocean Economic Research (Chinese), 2, 84-93.

Sugandha. (2008). Evolution of maritime strategy and national security of India, New Delhi: Decent Books. 
Unjhawala, Y. (2015). Sino-India rivalry in the Indian Ocean. Retrieved from http://swarajyamag.com/world/sino-india-rivalry-in-the-indian-ocean

Vines, A., \& Oruitemeka, B. (2008). India's engagement with the African Indian Ocean Rim States. London: Report of Chatham House. 